\title{
Assessing the Use of Learning Strategies among Young Malaysian English as Second Language Learners
}

\author{
Sarina Sani ${ }^{1}$, Hanita Hanim Ismail ${ }^{2}$ \\ ${ }^{1}$ SKA Ibnu Khaldun, Samarahan, Malaysia \\ ${ }^{2}$ Faculty of Education, Universiti Kebangsaan Malaysia, Bangi, Malaysia \\ Email: hanitaismail@ukm.edu.my
}

How to cite this paper: Sani, S., \& Ismail, H. H. (2021). Assessing the Use of Learning Strategies among Young Malaysian English as Second Language Learners. Creative Education, 12, 2124-2145.

https://doi.org/10.4236/ce.2021.129163

Received: July 21, 2021

Accepted: September 21, 2021

Published: September 24, 2021

Copyright $\odot 2021$ by author(s) and Scientific Research Publishing Inc. This work is licensed under the Creative Commons Attribution International License (CC BY 4.0).

http://creativecommons.org/licenses/by/4.0/

(c) (i) Open Access

\begin{abstract}
Past studies have discerned gender disparity in language learning strategy (LLS) used among English as a Second Language (ESL) secondary schools and university students. However, very few studies have been done on learners in primary schools, particularly young Malaysian learners. This study, therefore, identifies frequently used learning strategies between genders in ESL classroom. A total of 30 young Malaysian learners at the age of 10 were selected through purposive sampling in a suburban area in Samarahan, Sarawak. The close-ended Strategy Inventory for Language Learning (SILL) was employed as the data collection tool. Data were then analysed descriptively using SPSS Version 25. The findings showed that common LLS employed by young Malaysian ESL learners are compensation strategies where a teacher or peer interference fills the gap in communication and lack of vocabulary, leading to the use of compensation strategy. Besides that, it was found that female learners are likely to use more language strategies compared to male learners. Another interesting observation is that the commonly used strategies employed among female students are cognitive strategies while male learners preferred cognitive strategies. The teaching implications and recommendations for potential study are further considered.
\end{abstract}

\section{Keywords}

Gender Disparity, Language Learning Strategies, Malaysian, Commonly Used Strategies, Young Learners

\section{Introduction}

As English remains relevant as a lingua franca, language learners, including 
young learners, are expected to compete in future challenges in education, especially with the current demands of 21 st-century learning challenges. They must be proficient at collaboration, communication, and problem-solving skills, which are developed through social and emotional learning, as suggested by the World Economic Forum (2016). The report highlights the needed skills help young learners for lifelong learning and succeed in the evolving digital economy. Hence, the development of social and emotional skills becomes a shared goal and competency in recent education systems everywhere (World Economic Forum, 2016). This massive transformation in education and learning also reflects a shift in organisational revolution, industrial improvement, and labour business rivalry (Osman et al., 2010). This has led to changes in required capabilities to effectively compete with the evolving global economy. Hence, in 2012, the Malaysian Education Development Plan introduced learning skills that promote the 21st-century development (Muhamad \& Seng, 2019). Aziz (2018) viewed the introduction of a 21st-century approach to students' learning as a way to ensure that they are future-ready with the requisite competencies and expectations. Thus, this demands the education sector to prepare young learners for competency in order to give invaluable contributions to achieving this national objective (Garba et al., 2015).

However, language learners, especially young learners, are not aware of their knowledge of language since birth. They need to learn many things to comprehend different types of knowledge for future needs (Lee, 2010). As enacted in the National Education Policy 1970, English serves as L2 and is considered a compulsory subject to be taught in schools since the recommendation of the Razak Report in 1956 (Ramiza \& Albion, 2013). In the present day, English is elevated as an important subject where upon school exit, learners are expected to be proficient in English both in writing and communication as inspired in the recent Malaysia Education Blueprint. Hence, Malaysian primary school students between the age of 7 to 12 years old are required to learn English since it is considered an L2 in the country. However, there are differences in the capability of acquiring L2 among different language learners since some can adapt faster than others (Vance, 1999). As such, there is a need to investigate learning strategies used by learners to determine the effectiveness of their L2 learning and enable them to choose strategies that match their learning style (Subramaniam \& Palanisamy, 2014). Martínez (1996) highlighted that learners should be introduced to LLS by allowing them to select and experience strategies that suit them.

Since English is an established lingua franca, this creates a high demand for language competency among local undergraduates and postgraduates, especially in the employment sector (Padmaja \& Reddy, 2019). Studies on improving language proficiency are observable in many studies, taking in the perspectives of enhancing language skills such as reading (e.g. Al Raqqad et al., 2019; Rehman et al., 2020), writing (e.g. Chand, 2014), speaking (e.g. Wael et al., 2018; Syafryadin, 2020) and vocabulary (e.g. Asgari \& Mustapha, 2011). However, it is observed that Malaysian English learners are not adequately fluent, indicating their poor 
command of the language. There is a growing statistic of Malaysian students who cannot express themselves clearly nor write well in English, despite their early exposure to the language (Chong et al., 2011) which begins as early as 6 years old continues until they are 17 years old, making 11 years of learning ( $\mathrm{Da}$ vid et al., 2015). Despite this, there is an obvious rise of unemployed graduates as they lack competence and communication skills in English (Ting et al., 2017). Hence, it is important to offer a classroom condition that is effective not only in teaching but also in learning itself, especially in communication (Rusli et al., 2018). Apart from that, it is essential for learners to use LLS in order to develop communication competence (Padmaja \& Reddy, 2019).

Introducing young learners to learning strategies enables their control in learning during the process of becoming good language learners (Tahang et al., 2018). Serious work needs to start given the plethora of challenges that exist, especially in the education sector where there are many developments are made to produce good language learners, particularly in English communication. To date, language pedagogy has transited steadily from teacher-focused classrooms to students-focused classrooms, requiring L2 learners to improve their autonomous learning (Lessard-Clouston, 1997). In other words, Lessard-Clouston (1997) observed fewer stresses on teachers in teaching since learners are given more autonomy in their learning. In fact, learning strategies posit an important role in enabling autonomy among ESL learners.

\subsection{Research Objectives}

This paper mainly looked at two objectives-the need to identify the frequently used learning strategies among young ESL learners aged 10 years old, and to explore strategies used among the two genders. Since there is a need to understand students' learning strategies in order to help their mastery of L2, this study ultimately identified a variety of language strategies for teachers' consideration for classroom uses with young ESL learners. These different learning strategies can help teachers select the best method and approaches in teaching English.

\subsection{Research Questions}

1) What are young learners' most used language learning strategies in learning English?

2) What are the most used strategies for learning English by young male and female learners?

\section{Literature Review}

\subsection{Language Learning Strategies (LLS)}

LLS is seen as an assisting technique to bolster language learning (Saad et al., 2016). Some of the most prominent proponents in the field of LLS are influenced by Piaget's cognitive processes (Saad et al., 2016). According to Piaget (1964), children at the age of 10 , which falls into the concrete operations period and be- 
ginning part of the formal operations period, may grasp many ideas, particularly in language education and conceive possible alternatives in their learning. It is vital to remember that children at this age can think both concretely and abstractly, and their cognitive development permits them to process metacognition in terms of thinking and planning for themselves. Many of Piaget's works helped teachers understand children's cognitive development. Felix (1981) argued that students' greater cognitive capacity would most likely affect the direction of his L2 learning.

At present, the study of LLS is not only one of the most prominent research subjects, in both ESL and foreign language learning (EFL) (Wong \& Nunan, 2011), but also adds to significant education concerns at the national and global level (Simsek \& Balaban, 2010). Various empirical studies have helped the cognizance of essential aspects in LLS in acquiring L2 and foreign language (Weng et al., 2016). This section defines LLS and its importance in facilitating language learner autonomy.

Lee (2010) observed the varying definitions of LLS. One of the most frequently cited definitions in the literature is Oxford's (Zare, 2012). Learning strategies are steps taken by language learners to facilitate the whole process of acquisition, storage, retrieval, or using linguistic information (Swathi, 1990). While LLS is also a representation of what the learners want to do and actions taken during the learning process, meaning-making plays an important role in the process of language learning. Cohen (1998) pointed out that enabling meaning-making, which is chosen deliberately by students, can lead to measure in improving L2 learning by retaining, recalling and implementing language knowledge. Chamot (2004) described language learning as learners' conscious act and behaviour in acquiring a language. Hence, learning strategies are regarded as unique approaches to process knowledge that enhances understanding, learning, or information preservation (Zare, 2012).

\subsection{Classification of Language Learning Strategies}

To identify learning strategies, Swathi (1990) introduced a taxonomy of LLS that is divided into two major classifications, which are direct and indirect strategies. Table 1 illustrates its classification.

On the one hand, direct strategies are strategies that are involved directly in the learning acquisition and require the mental processing of the target language (Gerami \& Baighlou, 2011). It comprises three: memory, cognitive, and compensation strategies. The first sub-category of direct strategy is memory strategies, which are associated with meta-cognition, utilising pictures and rhymes, accepting knowledge positively, and engaging actions (Swathi, 1990). As it enables students to collect and store new knowledge, memory strategies facilitate learners in categorizing information as either continuous or temporary memory and retrieving it when necessary during learning tasks. Nemati (2009) indicated that learners can acquire higher memory retention if they can use suitable memory strategies in acquiring the language, such as being educated in the use of 
Table 1. Swathi's (1990) classification of language learning strategies.

\begin{tabular}{|c|c|c|}
\hline $\begin{array}{l}\text { Major Classification } \\
\text { of Learning Strategies }\end{array}$ & Types of Learning Strategies & Forms of Learning Strategies \\
\hline \multirow{3}{*}{ Direct Strategies } & Memory Strategies & $\begin{array}{l}\text { - creating mental linkages } \\
\text { - relating images and sounds to grammar } \\
\text { components } \\
\text { - reviewing the grammatical items } \\
\text { - employing actions }\end{array}$ \\
\hline & Cognitive Strategies & $\begin{array}{l}\text { - practicing grammar regularly } \\
\text { - receiving and sending messages } \\
\text { - analysing and reasoning } \\
\text { - creating structure for input and output }\end{array}$ \\
\hline & $\begin{array}{l}\text { Compensation } \\
\text { Strategies }\end{array}$ & $\begin{array}{l}\text { - guessing intelligently } \\
\text { - problem solving }\end{array}$ \\
\hline Indirect Strategies & $\begin{array}{c}\text { Metacognitive } \\
\text { Strategies }\end{array}$ & $\begin{array}{l}\text { - centralize the learning } \\
\text { - organizing and planning learning } \\
\text { - evaluating own learning } \\
\text { - lowering anxiety } \\
\text { - self-encouraging } \\
\text { - taking emotional temperature } \\
\text { - posing questions } \\
\text { - collaborating with others } \\
\text { - empathizing with others }\end{array}$ \\
\hline
\end{tabular}

strategies or exercising correctly with deeper involvement of words. The second category in direct strategies is cognitive strategies. Cognitive strategies allow students to comprehend and develop a new language in many ways. Swathi (1990) emphasised the importance of cognitive strategies as essential tools to control learning development and achieve language accomplishment, making it the most prevalent strategy among language learners (Syafryadin, 2020; Iamudom \& Tangkiengsirisin, 2020). Finally, the third type of direct strategies is compensation strategies, which empower learners to predict logically in communication as well as continuing genuine interactions with others. The compensation strategies are effective in creating an insufficient selection of language rules especially in vocabulary (Syafryadin, 2020). As compensation strategies involve guessing words with synonyms, Webb (2007) indicated that language attainment will be easier if learners are able to use words with the same meaning to convey a message both in communication and classroom activities.

The second major classification of learning strategy is indirect strategies, which are related to frequently promoting and administering language education with no overt participation in the target language (Gerami \& Baighlou, 2011). It is made up of metacognitive, affective, and social strategies. Swathi (1990) indicated that metacognitive strategies allow learners to control their own intellectual skills, preparing them for learning, tracking of self-planning, and self-assessment. Metacognitive strategies are related to an awareness that learners possess, where they know what needs to be done when they get overwhelmed and uncertain about what to do (Anderson, 2002). Anderson further explained that meta- 
cognitive strategies provokes one's thinking, which can lead to more profound learning and improved performance. Martínez (1996) added that metacognitive strategies involve understanding knowledge acquisition. The second category in indirect strategies is affective strategies, which refer to feelings, attitudes, inspiration, beliefs, and as well as creating self-confidence for learners (Swathi, 1990). Syafryadin (2020) explained that affective strategies are probably one of the biggest influences of language learning accomplishment or disappointment. It is positive emotions and attitudes that can increase the effectiveness and enjoyment of language learning (Viriya \& Sapsirin, 2014). This is because inculcating positive emotions in learners leads to superior achievement in language learning (Rahimi \& Bagdeli, 2014). The last sub-category in indirect strategies is social strategies that enhance interaction and generate empathic awareness. In order to be effective language users, learning language requires a great deal of communication between and among people (Viriya \& Sapsirin, 2014). Steels (2003) reiterated that learning is not only based on a sensory-motor device but also socially grounded through connections with others. Activities in social strategies help learners to possess good skills in negotiating activities and transacting with others (Syafryadin, 2020).

Oxford's taxonomy received appraisal and considered as the most comprehensive and detailed taxonomy of language learning (Zare, 2012). In another critique, the classifications offered a particular attribute towards the insights of each major and sub-category of LLS (Sepasdar \& Soori, 2014), and those characteristics provide a robust comprehension into the category of LLS (Chen, 2014).

\subsection{The Importance of LLS to Young Learners}

There are numerous studies on language acquisition which focusing on LLS within the past decades (e.g. Wong \& Nunan, 2011). However, Habok and Magyar (2018) highlighted that recent studies primarily looked into employing language strategies among university and high school students. There are fewer studies on understanding secondary students and young learners. Hence, this study saw the relevance of focusing on young ESL learners and associating the use of learning strategy in relation to gender differences. Investigating the LLS among young learners is significant as it could lead to greater understanding on achieving language mastery at an early stage during the process of language acquisition. Wong and Nunan (2011) highlighted that not all learning strategies best fit young learners. Learners' willingness to explore and identify suitable learning strategies are steps at improving comprehension of these LLS, which allows them to learn and develop their language learning autonomy effectively (Lee, 2010).

Wong and Nunan (2011), who are proponents of identifying learning strategies for language learners, observed an advantage of using learning strategies, which is learners' ability to utilise all the activities set in the classroom. This is a shred of evidence that shows learners, who consciously recognise and are in- 
formed about learning strategies, have high motivation to learn. Not only does it enable students to take more responsibilities in learning the language at their own will as well as seeing it as an individual advancement (Wong \& Nunan, 2011) but it also shapes effective learners (Lessard-Clouston, 1997). Enhancing student consciousness on learning strategies allow learners' assessment of their approach and learning efficacy (Yunus et al., 2013). Since they are young learners, it is the teacher's responsibility to guide and train their students in exploiting learning strategies.

\subsection{Past Studies}

In certain aspects of human social and cognitive development, gender differences have been observed in several studies. In the study of LSS, there are several experiments in different cultures suggesting females as the more frequent users than men (Zhou, 2010; Kaur \& Embi, 2011; Teh et al., 2009). Zhou (2010) in her study on senior high school students in China, asserted that female learners use more compensation, metacognitive and cognitive strategies than male learners. Teh et al. (2009) in their study in Malaysian secondary schools also revealed that female learners often appear to frequently use more compensation, affective and social strategies than male learners. Razak et al. (2012) also supported that female students exhibited higher frequencies in cognitive, metacognitive, and social learning strategies than male learners.

However, gender disparities are not inherently global. Wharton (2000) indicated that language strategies were widely used among male students in Singapore. This is because males were high users of L2, thus indicating no major variation in gender in the use of language strategies. In Tran's (1988) report, male Vietnamese migrants used more strategies than females in the United States. He said that both strategy choice and gender could be influenced by the job situation.

Certain studies provide an inconsistent indication regarding the gender difference in learning strategies use. Viriya and Sapsirin (2014) whose research is done on university students in Thailand, found no significant language variations between male and female students. This is because of the culture and educational system that limit opportunities to use practical language strategies, especially in a high number of learners in classes. This is also supported by Wafa (2003) in her study on university students in Palestine that there were no major variations between gender in the consumption of strategies. In Palestine, she said, students are more interested in passing examinations and answering questions, specifically those which are relevant to the material of their prescribed textbooks. The outcome of the study performed by Li (2020) similarly mentioned the use of learning strategies where gender for L2 learning did not vary significantly.

While the outcome is different and contentious, the idea of effective and successful language learners is interesting and worth studying. LLS should be clearly 
instructed as well as informed by both teachers and learners in order to increase performance in language acquisition. With regards to university students and high school teachers, there were also several experiments carried out. This study is, therefore, necessary to replicate the LLS employed by learners in the context of young learners for the research.

\section{Methods}

\subsection{Participants}

The participants of this study were 30 young ESL learners at the age of 10 who were selected through purposive sampling method. This method was chosen to ensure the sample retains the similar characteristics of the real population, namely young learners who can read English fluently. Learners' ability to read the survey questionnaire fluently is very much required so that they can fully understand the questionnaire. The number of young male and female respondents in the sample was equal to enable transparency of the findings, thus establishing the validity of the study (Razak et al., 2012). The equal distribution of 30 male and female respondents is shown in Table 2.

\subsection{Data Collection Instrument}

The main data collection instrument used in this study was Swathi's (1990) Strategy Inventory for Language Learning (SILL). Oxford's SILL is commonly used by researchers worldwide in studying LLS employed by learners (Habok \& Magyar, 2018). Lee (2010) posited that the SILL questionnaire is the more comprehensible and detailed instrument designed to test the learning strategy used by ESL/EFL learners. The complex questionnaire is divided into six category fields as explained in Table 3 below.

Table 2. Distribution of respondents by gender.

\begin{tabular}{ccc}
\hline Gender & Frequency & Percentage \\
\hline Male & 15 & 50 \\
Female & 15 & 50 \\
Total & 30 & 100 \\
\hline
\end{tabular}

Table 3. Description for each part of the questionnaire.

\begin{tabular}{cc} 
Strategies & Number of items \\
\hline Part A: Memory Strategies & 8 items \\
Part B: Cognitive Strategies & 9 items \\
Part C: Compensation Strategies & 6 items \\
Part D: Metacognitive Strategies & 8 items \\
Part E: Affective Strategies & 6 items \\
Part F: Social Strategies & 6 items \\
\hline
\end{tabular}


In order to show the extent to which the participants approve or disagree with certain statements based on their knowledge on LLS, the participants were requested to answer each statement based on a five-point Likert scale explained in Table 4.

\subsection{Data Collection Procedure}

The SILL questionnaire was administered after English classes for three days with an approximation of 15 - 20 minutes for completion. The study was authorised by the school administration and permitted by the teachers. Participants were also informed of their participation and assured of their privacy and confidentiality in the research, ascertaining that there were no implications on grades. The survey administration was done for three days as adolescents of 10 generally have a short attention span; hence, the researchers placed great importance on making sure that participants were able to understand the questions. This was ensured by separating parts of the questions in different days.

\subsection{Data Collection Analysis}

The data were then analysed using descriptive analysis from SPSS. It facilitated responses for examination in order to understand the respondents' overall use of LLS, besides identifying the commonly used strategy among young learners. An interpretation of the mean score was employed to identify the learning strategies used.

\section{Findings and Discussion}

\subsection{The Overall Language Learning Strategies}

The mean for each strategy is demonstrated in Table 5 below. Swathi (1990) divided learning strategies into two main groups: direct strategies (memory, cognitive, and compensation) and indirect strategies (metacognitive, affective, and social strategies). For this study, the young learners were reported to use indirect strategies more than direct strategies. The table indicates mean scores for each of the LLS that range from 2.85 to 3.38 for these strategies. The table also shows the rank for each strategy.

As shown in Table 5, it can be observed that all the six LLS were being used by the respondents. Compensation strategies are the most used by young learners

Table 4. Likert-scale description for each language learning strategy statement.

\begin{tabular}{cc}
\hline Scale & Description \\
\hline 1 & Never or almost never true \\
2 & Usually not true \\
3 & Somewhat true \\
4 & Usually true \\
5 & Always or almost always true
\end{tabular}


Table 5. Mean score for each language learning strategy.

\begin{tabular}{ccccc}
\hline No & $\begin{array}{c}\text { Major Classification of } \\
\text { Learning Strategies }\end{array}$ & Learning Strategies & Mean Scores & Ranking \\
\hline 1 & Direct Strategies & Memory strategies & 2.85 & $6^{\text {th }}$ \\
2 & & Cognitive strategies & 3.01 & $4^{\text {th }}$ \\
3 & & Compensation strategies & 3.38 & $1^{\text {st }}$ \\
& Mean for direct strategies & 3.08 & \\
4 & Indirect Strategies & Metacognitive strategies & 3.34 & $3^{\text {rd }}$ \\
5 & & Affective strategies & 2.88 & $5^{\text {th }}$ \\
6 & & Social strategies & 3.36 & $2^{\text {nd }}$ \\
& & Mean for indirect strategies & 3.19 & \\
\hline
\end{tabular}

with a mean score of 3.38. The respondents were also reported to frequently use another four strategies based on descending order which are social, metacognitive, cognitive and affective strategies, with the mean scores between 3.36 and 2.88. Memory strategies recorded the lowest mean score of 2.85 , indicating it is the least used strategies by the respondents.

\subsection{Analysis for Individual Strategy Use}

Below are recorded findings of the individual strategy used by the respondents. It comprises the percentage of responses, frequency of the number of respondents in brackets, and the mean score for each strategy.

\subsubsection{Memory Strategies}

Based on responses from 30 respondents, findings reveal the most used strategy in memory strategies. There are 8 items in the category that are listed as Q1 - Q8 in Table 6. The mean score for Q1 suggests that young learners preferred to memorise words in English by making mental pictures of learned situations where words were used. In other words, they preferred imagery which includes visualising figures as their language attainment. Hence, teachers' repeated practice of this strategy will most likely empower learners to possess higher retention in learning new items or words. This supports Nemati's (2009) suggestion of using a suitable memorising activity which leads to better retention among the learners.

In addition, the respondents preferred the integration of sounds when learning English. With a mean score of 3.30, item Q2 indicated that the respondents connected the sound of new images or pictures of the word in association with remembering new words. Such association is employed in memory strategies where learners utilise both pictures and rhymes to store and collect new words (Swathi, 1990).

However, the least used strategy is the use of new English words in a sentence. The respondents might have difficulty implementing this strategy since their exposure to English is quite limited. This indicates that young learners require a 
Table 6. Score for memory strategies.

\begin{tabular}{|c|c|c|c|c|c|c|c|}
\hline \multirow{2}{*}{\multicolumn{2}{|c|}{ Item }} & $\begin{array}{l}\text { Never or almost } \\
\text { never true }\end{array}$ & $\begin{array}{l}\text { Usually } \\
\text { not true }\end{array}$ & $\begin{array}{l}\text { Somewhat } \\
\text { true }\end{array}$ & $\begin{array}{l}\text { Usually } \\
\text { true }\end{array}$ & $\begin{array}{l}\text { Always or } \\
\text { almost true }\end{array}$ & \multirow[t]{2}{*}{$\begin{array}{l}\text { Mean } \\
\text { score }\end{array}$} \\
\hline & & 1 & 2 & 3 & 4 & 5 & \\
\hline \multicolumn{8}{|c|}{ Part A: Memory Strategies } \\
\hline Q1. & $\begin{array}{l}\text { I use new English words in a sentence so I can remember } \\
\text { them. }\end{array}$ & $\begin{array}{l}40 \% \\
(12)\end{array}$ & $\begin{array}{l}17 \% \\
(5)\end{array}$ & $\begin{array}{l}13 \% \\
(4)\end{array}$ & $\begin{array}{l}17 \% \\
(5)\end{array}$ & $\begin{array}{c}13 \% \\
(4)\end{array}$ & 2.47 \\
\hline Q2. & $\begin{array}{l}\text { I connect the sound of a new English word and an image or } \\
\text { picture of the word to help remember the word. }\end{array}$ & $\begin{array}{l}7 \% \\
(2)\end{array}$ & $\begin{array}{c}23 \% \\
(7)\end{array}$ & $\begin{array}{c}23 \% \\
(7)\end{array}$ & $\begin{array}{c}27 \% \\
(8)\end{array}$ & $\begin{array}{c}20 \% \\
(6)\end{array}$ & 3.30 \\
\hline Q3. & $\begin{array}{l}\text { I remember a new English word by making a mental picture } \\
\text { of a situation in which the word might be used. }\end{array}$ & $\begin{array}{l}10 \% \\
(3)\end{array}$ & $\begin{array}{l}17 \% \\
(5)\end{array}$ & $\begin{array}{l}17 \% \\
(5)\end{array}$ & $\begin{array}{l}43 \% \\
(13)\end{array}$ & $\begin{array}{c}13 \% \\
(4)\end{array}$ & 3.33 \\
\hline Q4. & I use rhymes to remember new English words. & $\begin{array}{l}33 \% \\
(10)\end{array}$ & $\begin{array}{l}7 \% \\
(2)\end{array}$ & $\begin{array}{c}23 \% \\
(7)\end{array}$ & $\begin{array}{c}27 \% \\
(8)\end{array}$ & $\begin{array}{l}10 \% \\
(3)\end{array}$ & 2.73 \\
\hline Q5. & I use flashcards to remember new English words. & $\begin{array}{c}23 \% \\
(7)\end{array}$ & $\begin{array}{c}10 \% \\
(3)\end{array}$ & $\begin{array}{c}20 \% \\
(6)\end{array}$ & $\begin{array}{l}47 \% \\
(14)\end{array}$ & $\begin{array}{l}0 \% \\
(0)\end{array}$ & 2.90 \\
\hline Q6. & I physically act out new English words. & $\begin{array}{c}30 \% \\
(9)\end{array}$ & $\begin{array}{c}20 \% \\
(6)\end{array}$ & $\begin{array}{c}23 \% \\
(7)\end{array}$ & $\begin{array}{c}23 \% \\
(7)\end{array}$ & $\begin{array}{l}4 \% \\
(1)\end{array}$ & 2.50 \\
\hline Q7. & I review English lessons often. & $\begin{array}{c}17 \% \\
(5)\end{array}$ & $\begin{array}{c}30 \% \\
(9)\end{array}$ & $\begin{array}{c}30 \% \\
(9)\end{array}$ & $\begin{array}{c}23 \% \\
(7)\end{array}$ & $\begin{array}{l}0 \% \\
(0)\end{array}$ & 2.60 \\
\hline Q8. & $\begin{array}{l}\text { I remember new English words or phrases by remembering } \\
\text { their location on the page, on the board, or on a street sign. }\end{array}$ & $\begin{array}{l}3 \% \\
(1)\end{array}$ & $\begin{array}{c}30 \% \\
(9)\end{array}$ & $\begin{array}{l}37 \% \\
(11)\end{array}$ & $\begin{array}{l}23 \% \\
(7)\end{array}$ & $\begin{array}{l}7 \% \\
(2)\end{array}$ & 3.00 \\
\hline
\end{tabular}

lot of practice in memory strategies to boost their memory capacity as well as use the language efficiently.

\subsubsection{Cognitive Strategies}

Table 7 indicates Items Q9 - Q15 under cognitive strategies. There are 9 items that support the strategies in the category. Based on item Q10, almost a majority of the respondents (47\%) imitated native speakers as their most commonly used strategies. This shows that these young learners preferred to imitate the way native speakers speak in order to learn English. Imitating the spoken sentence structure and applying it in similar situations is easier.

Item Q14, with the second highest mean score (3.57), reveals another significant strategy that the respondents employed, which is watching television shows or movies in English. Television channels offer interesting English-speaking channels for children around the world. Whenever they return home from school, they spend most of their time watching television or using other devices that use English as a medium of language. Online or offline games, for example, are known to use English as the intermediary language in the software or application as well as in other devices. Thus, this explains young learners' regular use of this strategy.

However, their least strategy is starting a conversation in English (as indicated in Item Q13). Such low preference can probably be due to their limited vocabularies, hence, their hesitance to start a conversation in English. They might have 
Table 7. Score for cognitive strategies.

\begin{tabular}{|c|c|c|c|c|c|c|}
\hline \multirow[t]{2}{*}{ Item } & $\begin{array}{c}\text { Never or almost } \\
\text { never true }\end{array}$ & $\begin{array}{l}\text { Usually } \\
\text { not true }\end{array}$ & $\begin{array}{c}\text { Somewhat } \\
\text { true }\end{array}$ & $\begin{array}{l}\text { Usually } \\
\text { true }\end{array}$ & $\begin{array}{l}\text { Always or } \\
\text { almost true }\end{array}$ & \multirow[t]{2}{*}{ Mean score } \\
\hline & 1 & 2 & 3 & 4 & 5 & \\
\hline \multicolumn{7}{|c|}{ Part B: Cognitive Strategies } \\
\hline Q9. I say or write new English words several times. & $\begin{array}{c}13 \% \\
(4)\end{array}$ & $\begin{array}{c}17 \% \\
(5)\end{array}$ & $\begin{array}{c}20 \% \\
(6)\end{array}$ & $\begin{array}{l}33 \% \\
(10)\end{array}$ & $\begin{array}{c}17 \% \\
(5)\end{array}$ & 3.23 \\
\hline Q10. I try to talk like native English speakers. & $\begin{array}{l}6 \% \\
(2)\end{array}$ & $\begin{array}{c}20 \% \\
(6)\end{array}$ & $\begin{array}{l}0 \% \\
(0)\end{array}$ & $\begin{array}{c}27 \% \\
(8)\end{array}$ & $\begin{array}{l}47 \% \\
(14)\end{array}$ & 3.87 \\
\hline Q11. I practice the sounds of English. & $\begin{array}{l}7 \% \\
(2)\end{array}$ & $\begin{array}{l}20 \% \\
(6)\end{array}$ & $\begin{array}{c}13 \% \\
(4)\end{array}$ & $\begin{array}{l}37 \% \\
(11)\end{array}$ & $\begin{array}{c}23 \% \\
(7)\end{array}$ & 3.50 \\
\hline Q12. I use the English words I know in different ways. & $\begin{array}{c}10 \% \\
(3)\end{array}$ & $\begin{array}{c}20 \% \\
(6)\end{array}$ & $\begin{array}{l}37 \% \\
(11)\end{array}$ & $\begin{array}{c}30 \% \\
(9)\end{array}$ & $\begin{array}{l}3 \% \\
(1)\end{array}$ & 2.97 \\
\hline Q13. I start conversations in English. & $\begin{array}{c}27 \% \\
(8)\end{array}$ & $\begin{array}{l}47 \% \\
(14)\end{array}$ & $\begin{array}{c}17 \% \\
(5)\end{array}$ & $\begin{array}{l}3 \% \\
(1)\end{array}$ & $\begin{array}{l}6 \% \\
(2)\end{array}$ & 2.17 \\
\hline $\begin{array}{l}\text { Q14. watch English language TV shows spoken in English } \\
\text { or go to movies spoken in English. }\end{array}$ & $\begin{array}{c}17 \% \\
(5)\end{array}$ & $\begin{array}{c}13 \% \\
(4)\end{array}$ & $\begin{array}{l}7 \% \\
(2)\end{array}$ & $\begin{array}{c}23 \% \\
(7)\end{array}$ & $\begin{array}{l}40 \% \\
(12)\end{array}$ & 3.57 \\
\hline Q15. I read for pleasure in English. & $\begin{array}{l}3 \% \\
(1)\end{array}$ & $\begin{array}{l}44 \% \\
(13)\end{array}$ & $\begin{array}{c}30 \% \\
(9)\end{array}$ & $\begin{array}{c}20 \% \\
(6)\end{array}$ & $\begin{array}{l}3 \% \\
(1)\end{array}$ & 2.77 \\
\hline Q16. I write notes, messages, letters, or reports in English. & $\begin{array}{c}10 \% \\
(3)\end{array}$ & $\begin{array}{l}53 \% \\
(16)\end{array}$ & $\begin{array}{c}20 \% \\
(6)\end{array}$ & $\begin{array}{c}17 \% \\
(5)\end{array}$ & $\begin{array}{l}0 \% \\
(0)\end{array}$ & 2.43 \\
\hline $\begin{array}{l}\text { I first skim an English passage (read over the passage } \\
\text { quickly) then go back and read carefully. }\end{array}$ & $\begin{array}{l}6 \% \\
(2)\end{array}$ & $\begin{array}{l}47 \% \\
(14)\end{array}$ & $\begin{array}{c}30 \% \\
(9)\end{array}$ & $\begin{array}{c}17 \% \\
(5)\end{array}$ & $\begin{array}{l}0 \% \\
(0)\end{array}$ & 2.57 \\
\hline
\end{tabular}

the courage to start a conversation in their mother tongue but not in English due to the limitation of expressions or terminology they possess.

\subsubsection{Compensation Strategies}

Item Q18 in Table 8 shows that young learners preferred to guess if they encounter unfamiliar words. This strategy requires them to use linguistic clues whenever communication breakdown occurs. Swathi (1990) explained that the use of compensation strategies will enable learners to resolve any language learning problem encountered by guessing intelligently and overcoming limitations in speaking or writing. This is exactly what the respondents did to overcome language barriers with their peers or people around them. Apart from that, Item Q23 shows that 63\% of the respondents employed the use of words or phrases that are synonymous. Webb (2007) indicated that words with known synonyms are easier to be learnt, thus facilitating the language attainment. Therefore, teachers and learners need to be aware that teaching and learning strategies that strengthen links between synonyms may improve learning.

In compensation strategies, the least used strategy among the respondents is in Item Q21 where 37\% of the respondents read English without looking up every new word. This reveals that young learners did not over-depend on dictionaries when reading English materials. As they are young learners, they might not have the skill to look for words in the dictionary nor have sufficient knowledge 
Table 8. Score for compensation strategies.

\begin{tabular}{|c|c|c|c|c|c|c|c|}
\hline \multirow{2}{*}{\multicolumn{2}{|c|}{ Item }} & $\begin{array}{l}\text { Never or almost } \\
\text { never true }\end{array}$ & $\begin{array}{l}\text { Usually } \\
\text { not true }\end{array}$ & $\begin{array}{l}\text { Somewhat } \\
\text { true }\end{array}$ & $\begin{array}{l}\text { Usually } \\
\text { true }\end{array}$ & $\begin{array}{l}\text { Always or } \\
\text { almost true }\end{array}$ & \multirow[t]{2}{*}{ Mean score } \\
\hline & & 1 & 2 & 3 & 4 & 5 & \\
\hline \multicolumn{8}{|c|}{ Part C: Compensation Strategies } \\
\hline Q18. & $\begin{array}{l}\text { To understand unfamiliar English words, I make } \\
\text { guesses. }\end{array}$ & $\begin{array}{l}3 \% \\
(1)\end{array}$ & $\begin{array}{l}17 \% \\
(5)\end{array}$ & $\begin{array}{l}53 \% \\
(16)\end{array}$ & $\begin{array}{c}27 \% \\
(8)\end{array}$ & $\begin{array}{l}0 \% \\
(0)\end{array}$ & 4.03 \\
\hline Q19. & $\begin{array}{l}\text { When I can't think of a word during a conversation in } \\
\text { English, I use gestures. }\end{array}$ & $\begin{array}{l}7 \% \\
(2)\end{array}$ & $\begin{array}{c}23 \% \\
(7)\end{array}$ & $\begin{array}{l}10 \% \\
(3)\end{array}$ & $\begin{array}{l}40 \% \\
(12)\end{array}$ & $\begin{array}{l}20 \% \\
(6)\end{array}$ & 3.43 \\
\hline Q20. & $\begin{array}{l}\text { I make up new words if I do not know the right ones in } \\
\text { English. }\end{array}$ & $\begin{array}{l}0 \% \\
(0)\end{array}$ & $\begin{array}{c}19 \% \\
(6)\end{array}$ & $\begin{array}{c}27 \% \\
(8)\end{array}$ & $\begin{array}{l}27 \% \\
(8)\end{array}$ & $\begin{array}{c}27 \% \\
(8)\end{array}$ & 3.60 \\
\hline Q21. & I read English without looking up every new word. & $\begin{array}{l}37 \% \\
(11)\end{array}$ & $\begin{array}{l}23 \% \\
(7)\end{array}$ & $\begin{array}{l}30 \% \\
(9)\end{array}$ & $\begin{array}{l}10 \% \\
(3)\end{array}$ & $\begin{array}{l}0 \% \\
(0)\end{array}$ & 2.13 \\
\hline Q22. & $\begin{array}{l}\text { I try to guess what the other person will say next in } \\
\text { English. }\end{array}$ & $\begin{array}{l}0 \% \\
(0)\end{array}$ & $\begin{array}{c}27 \% \\
(8)\end{array}$ & $\begin{array}{c}27 \% \\
(8)\end{array}$ & $\begin{array}{l}19 \% \\
(6)\end{array}$ & $\begin{array}{c}27 \% \\
(8)\end{array}$ & 3.47 \\
\hline Q23. & $\begin{array}{l}\text { If I can't think of an English word, I use a word or } \\
\text { phrase that means the same thing. }\end{array}$ & $\begin{array}{l}3 \% \\
(1)\end{array}$ & $\begin{array}{l}3 \% \\
(1)\end{array}$ & $\begin{array}{c}23 \% \\
(7)\end{array}$ & $\begin{array}{l}63 \% \\
(19)\end{array}$ & $\begin{array}{l}7 \% \\
(2)\end{array}$ & 3.67 \\
\hline
\end{tabular}

to find words in the dictionary. Hence, teachers could consider teaching the young learners to start using a dictionary to learn new English words.

\subsubsection{Metacognitive Strategies}

Items Q24 - Q31 in Table 9 include scores under metacognitive strategies. Based on the mean score, in Q29, 13\% of the respondents preferred to look for people with whom they can converse in English. This indicates that the young learners have the determination to self-monitor themselves as they realise that they need someone who can help them to develop their language learning skills. This shows that they are able to reflect on their own learning and as suggested by Anderson (2002) whenever learners are able to reflect upon their learning strategies, they come to be better equipped to make practical choices to enhance their learning. Apart from that, Item Q27, which is the second most used strategy, indicated that $37 \%$ of the respondents strived to become better ESL learners. This revealed that young learners tend to figure out what they need to do in language acquisition despite their young age, which echoes Anderson's (2002) observation on learners' initiative to improve themselves. In this case, it is through the use of metacognitive strategies which ignites one's thought, leading to deep learning and improving performances, particularly in language learning.

The second strategies least used by the samples are observed in Item Q30 (3.13), which is to look for opportunities to read more English materials. This demonstrates that young learners have little interest in reading English materials. From this analysis, a teacher should identify interesting reading materials to attract young learners to read English material as well as nurture a reading habit among them. Item Q28 (2.03) was the least frequently used strategy by the respondents. The respondents predominantly disagreed having scheduled and 
Table 9. Score for metacognitive strategies.

\begin{tabular}{|c|c|c|c|c|c|c|}
\hline \multirow[t]{2}{*}{ Item } & $\begin{array}{l}\text { Never or almost } \\
\text { never true }\end{array}$ & $\begin{array}{l}\text { Usually } \\
\text { not true }\end{array}$ & $\begin{array}{l}\text { Somewhat } \\
\text { true }\end{array}$ & $\begin{array}{l}\text { Usually } \\
\text { true }\end{array}$ & $\begin{array}{l}\text { Always or } \\
\text { almost true }\end{array}$ & \multirow[t]{2}{*}{ Mean score } \\
\hline & 1 & 2 & 3 & 4 & 5 & \\
\hline \multicolumn{7}{|c|}{ Part D: Metacognitive Strategies } \\
\hline Q24. I try to find as many ways as I can to use my English. & $\begin{array}{l}7 \% \\
(2)\end{array}$ & $\begin{array}{l}7 \% \\
(2)\end{array}$ & $\begin{array}{c}23 \% \\
(7)\end{array}$ & $\begin{array}{l}43 \% \\
(13)\end{array}$ & $\begin{array}{l}20 \% \\
(6)\end{array}$ & 3.63 \\
\hline $\begin{array}{l}\text { Q25. notice my English mistakes and use that information } \\
\text { to help me do better. }\end{array}$ & $\begin{array}{c}10 \% \\
(3)\end{array}$ & $\begin{array}{c}13 \% \\
(4)\end{array}$ & $\begin{array}{c}20 \% \\
(6)\end{array}$ & $\begin{array}{l}37 \% \\
(11)\end{array}$ & $\begin{array}{c}20 \% \\
(6)\end{array}$ & 3.43 \\
\hline Q26. I pay attention when someone is speaking English. & $\begin{array}{c}13 \% \\
(4)\end{array}$ & $\begin{array}{c}10 \% \\
(3)\end{array}$ & $\begin{array}{l}20 \% \\
(6)\end{array}$ & $\begin{array}{l}17 \% \\
(5)\end{array}$ & $\begin{array}{l}40 \% \\
(12)\end{array}$ & 3.60 \\
\hline Q27. I try to find out how to be a better learner of English. & $\begin{array}{l}7 \% \\
(2)\end{array}$ & $\begin{array}{c}13 \% \\
(4)\end{array}$ & $\begin{array}{c}13 \% \\
(4)\end{array}$ & $\begin{array}{l}30 \% \\
(9)\end{array}$ & $\begin{array}{l}37 \% \\
(11)\end{array}$ & 3.77 \\
\hline $\begin{array}{l}\text { Q28. I plan my schedule so I will have enough time to study } \\
\text { English. }\end{array}$ & $\begin{array}{l}37 \% \\
(11)\end{array}$ & $\begin{array}{l}33 \% \\
(10)\end{array}$ & $\begin{array}{c}20 \% \\
(6)\end{array}$ & $\begin{array}{c}10 \% \\
(3)\end{array}$ & $\begin{array}{l}0 \% \\
(0)\end{array}$ & 2.03 \\
\hline Q29. I look for people I can talk to in English. & $\begin{array}{l}0 \% \\
(0)\end{array}$ & $\begin{array}{l}7 \% \\
(2)\end{array}$ & $\begin{array}{l}20 \% \\
(6)\end{array}$ & $\begin{array}{l}60 \% \\
(18)\end{array}$ & $\begin{array}{c}13 \% \\
(4)\end{array}$ & 3.80 \\
\hline $\begin{array}{l}\text { Q30. look for opportunities to read as much as possible in } \\
\text { English. }\end{array}$ & $\begin{array}{l}0 \% \\
(0)\end{array}$ & $\begin{array}{c}23 \% \\
(7)\end{array}$ & $\begin{array}{l}47 \% \\
(14)\end{array}$ & $\begin{array}{c}23 \% \\
(7)\end{array}$ & $\begin{array}{l}7 \% \\
(2)\end{array}$ & 3.13 \\
\hline Q31. I have clear goals for improving my English skills. & $\begin{array}{l}0 \% \\
(0)\end{array}$ & $\begin{array}{c}17 \% \\
(5)\end{array}$ & $\begin{array}{l}40 \% \\
(12)\end{array}$ & $\begin{array}{l}40 \% \\
(12)\end{array}$ & $\begin{array}{l}3 \% \\
(1)\end{array}$ & 3.30 \\
\hline
\end{tabular}

particular allotted time to study English. They probably did not consider English learning as imperative as other subjects like Science or Mathematics for instance, and therefore, paid less attention to self-study the language.

\subsubsection{Affective Strategies}

There are 8 items under affective strategies and Table 10 reveals the score of Item Q32 - Q37 for the strategies. The result for Item Q33 reveals that $60 \%$ of the respondents preferred to encourage themselves to speak English when they are afraid of making mistakes. This shows that young learners are able to encourage and motivate themselves in language attainment, which includes managing learners' emotions, attitudes, motivations, and values (Swathi, 1990). As such, teachers ought to see the significance of their role in instilling positive emotions and attitudes in language learning, as it enables learners to learn effectively (Viriya \& Sapsirin, 2014).

Their least strategy used that lies under affective strategies is Item Q35 (I notice if I am tense or nervous when I am studying or using English). It is found that $57 \%$ of the respondents are not anxious when learning English. Although this is the least used strategy, it signifies a positive indicator that young learners enjoy learning English. For teachers, this is a great opportunity to improve and expand their approaches, methods, and techniques in teaching English as fun and enjoyable learning environment. Teachers need to create a classroom that enriches pleasurable emotions (Rahimi \& Bigdeli, 2014) that the combination of 
Table 10. Score for affective strategies.

\begin{tabular}{|c|c|c|c|c|c|c|c|}
\hline \multirow{2}{*}{\multicolumn{2}{|c|}{ Item }} & $\begin{array}{l}\text { Never or almost } \\
\text { never true }\end{array}$ & $\begin{array}{l}\text { Usually } \\
\text { not true }\end{array}$ & $\begin{array}{l}\text { Somewhat } \\
\text { true }\end{array}$ & $\begin{array}{l}\text { Usually } \\
\text { true }\end{array}$ & $\begin{array}{l}\text { Always or } \\
\text { almost true }\end{array}$ & \multirow{2}{*}{ Mean score } \\
\hline & & 1 & 2 & 3 & 4 & 5 & \\
\hline \multicolumn{8}{|c|}{ Part E: Affective Strategies } \\
\hline Q32. & I try to relax whenever I feel afraid of using English. & $\begin{array}{c}13 \% \\
(4)\end{array}$ & $\begin{array}{l}40 \% \\
(12)\end{array}$ & $\begin{array}{l}33 \% \\
(10)\end{array}$ & $\begin{array}{c}14 \% \\
(4)\end{array}$ & $\begin{array}{l}0 \% \\
(0)\end{array}$ & 2.47 \\
\hline Q33. & $\begin{array}{l}\text { I encourage myself to speak English even when I am } \\
\text { afraid of making a mistake. }\end{array}$ & $\begin{array}{l}0 \% \\
(0)\end{array}$ & $\begin{array}{c}10 \% \\
(3)\end{array}$ & $\begin{array}{c}13 \% \\
(4)\end{array}$ & $\begin{array}{l}17 \% \\
(5)\end{array}$ & $\begin{array}{l}60 \% \\
(18)\end{array}$ & 4.27 \\
\hline Q34. & $\begin{array}{l}\text { I give myself a reward or treat when I do well in } \\
\text { English. }\end{array}$ & $\begin{array}{l}23 \% \\
(7)\end{array}$ & $\begin{array}{l}37 \% \\
(11)\end{array}$ & $\begin{array}{l}17 \% \\
(5)\end{array}$ & $\begin{array}{c}10 \% \\
(3)\end{array}$ & $\begin{array}{c}13 \% \\
(4)\end{array}$ & 2.53 \\
\hline Q35. & $\begin{array}{l}\text { I notice if I am tense or nervous when I am studying or } \\
\text { using English. }\end{array}$ & $\begin{array}{l}57 \% \\
(17)\end{array}$ & $\begin{array}{l}33 \% \\
(10)\end{array}$ & $\begin{array}{c}10 \% \\
(3)\end{array}$ & $\begin{array}{l}0 \% \\
(0)\end{array}$ & $\begin{array}{l}0 \% \\
(0)\end{array}$ & 1.53 \\
\hline Q36. & I write down my feelings in language learning diary. & $\begin{array}{l}30 \% \\
(9)\end{array}$ & $\begin{array}{c}17 \% \\
(5)\end{array}$ & $\begin{array}{c}17 \% \\
(5)\end{array}$ & $\begin{array}{c}13 \% \\
(4)\end{array}$ & $\begin{array}{c}23 \% \\
(7)\end{array}$ & 2.83 \\
\hline Q37. & $\begin{array}{l}\text { I talk to someone else about how I feel when I am } \\
\text { learning English. }\end{array}$ & $\begin{array}{l}3 \% \\
(1)\end{array}$ & $\begin{array}{c}17 \% \\
(5)\end{array}$ & $\begin{array}{c}20 \% \\
(6)\end{array}$ & $\begin{array}{c}27 \% \\
(8)\end{array}$ & $\begin{array}{l}33 \% \\
(10)\end{array}$ & 3.70 \\
\hline
\end{tabular}

learners' positive emotions and the creation of pleasant emotions in learning, enables a greater degree of achievement in language learning.

\subsubsection{Social Strategies}

Table 11 encloses 6 items (Q38 - Q43) that reveal the scores under social strategies.

Item Q38 indicated that $50 \%$ of the respondents preferred to ask another person to slow down or repeat the words if they do not understand something uttered in English. This illustrates that the respondents were developing an environment for a two-way communication with peers or people around them in speaking English.

However, the strategy they used the least under social strategies is in Item Q43, which indicates only $27 \%$ of the respondents will try to learn about the culture of English speakers. It reveals that a few of the respondents try to learn cultures that enable them to give words the right meaning. As being of young age, the respondents do not yet know the virtues of understanding the culture of others and might have less exposure to the strategy. Therefore, teachers should encourage placing new words or information in a cultural context as it enables learners to engage at a different level with the language. Learning about how native people live and talk introduces a human side to the language, which keeps them hooked on the learning process.

\subsection{The Learning Strategy Used by Male and Female Young Learners}

Table 12 displays the strategies most used by young female and male learners. The overall mean shows that female learners used more strategies compared to 
Table 11. Score for social strategies.

\begin{tabular}{|c|c|c|c|c|c|c|}
\hline \multirow[t]{2}{*}{ Item } & $\begin{array}{l}\text { Never or almost } \\
\text { never true }\end{array}$ & $\begin{array}{l}\text { Usually } \\
\text { not true }\end{array}$ & $\begin{array}{l}\text { Somewhat } \\
\text { true }\end{array}$ & $\begin{array}{l}\text { Usually } \\
\text { true }\end{array}$ & $\begin{array}{l}\text { Always or } \\
\text { almost true }\end{array}$ & Mean score \\
\hline & 1 & 2 & 3 & 4 & 5 & \\
\hline \multicolumn{7}{|c|}{ Part F: Social Strategies } \\
\hline $\begin{array}{l}\text { Q38. If I do not understand something in English, I ask the } \\
\text { other person to slow down or say it again. }\end{array}$ & $\begin{array}{c}10 \% \\
(3)\end{array}$ & $\begin{array}{l}0 \% \\
(0)\end{array}$ & $\begin{array}{c}13 \% \\
(4)\end{array}$ & $\begin{array}{c}27 \% \\
(8)\end{array}$ & $\begin{array}{l}50 \% \\
(15)\end{array}$ & 4.07 \\
\hline Q39. I ask English speakers to correct me when I talk. & $\begin{array}{c}10 \% \\
(3)\end{array}$ & $\begin{array}{c}17 \% \\
(5)\end{array}$ & $\begin{array}{c}27 \% \\
(8)\end{array}$ & $\begin{array}{l}37 \% \\
(11)\end{array}$ & $\begin{array}{c}10 \% \\
(3)\end{array}$ & 3.20 \\
\hline Q40. I practise English with other students. & $\begin{array}{c}10 \% \\
(3)\end{array}$ & $\begin{array}{l}7 \% \\
(2)\end{array}$ & $\begin{array}{c}27 \% \\
(8)\end{array}$ & $\begin{array}{l}40 \% \\
(12)\end{array}$ & $\begin{array}{c}17 \% \\
(5)\end{array}$ & 3.47 \\
\hline Q41. I ask for help from English speakers. & $\begin{array}{l}7 \% \\
(2)\end{array}$ & $\begin{array}{c}13 \% \\
(4)\end{array}$ & $\begin{array}{c}27 \% \\
(8)\end{array}$ & $\begin{array}{c}27 \% \\
(8)\end{array}$ & $\begin{array}{c}27 \% \\
(8)\end{array}$ & 3.53 \\
\hline Q42. I ask questions in English. & $\begin{array}{c}13 \% \\
(4)\end{array}$ & $\begin{array}{l}0 \% \\
(0)\end{array}$ & $\begin{array}{l}20 \% \\
(6)\end{array}$ & $\begin{array}{c}27 \% \\
(8)\end{array}$ & $\begin{array}{l}40 \% \\
(12)\end{array}$ & 3.80 \\
\hline Q43. I try to learn about the culture of English speakers. & $\begin{array}{c}17 \% \\
(5)\end{array}$ & $\begin{array}{l}56 \% \\
(17)\end{array}$ & $\begin{array}{c}27 \% \\
(8)\end{array}$ & $\begin{array}{l}0 \% \\
(0)\end{array}$ & $\begin{array}{l}0 \% \\
(0)\end{array}$ & 2.10 \\
\hline
\end{tabular}

Table 12. Mean scores for female and male learning strategies.

\begin{tabular}{ccc}
\hline Learning strategies & $\begin{array}{c}\text { Male } \\
\text { Mean Scores }\end{array}$ & $\begin{array}{c}\text { Female } \\
\text { Mean Score }\end{array}$ \\
\hline Memory strategies & 1.49 & 1.47 \\
Cognitive strategies & 1.72 & 1.90 \\
Compensation strategies & 1.37 & 1.36 \\
Metacognitive strategies & 1.70 & 1.70 \\
Affective strategies & 1.07 & 1.20 \\
Social strategies & 1.30 & 1.24 \\
Total mean & 1.441 & 1.478 \\
\hline
\end{tabular}

male learners.

Based on the mean score, the female learners recorded 1.478 and the male learners scored 1.441. Although there is a slight difference in the mean score, it reveals that female learners used more strategies than male learners. This supports the study carried out by Zhou (2010), Kaur and Embi (2011), and Teh et al. (2009) in which they reported similar findings. Female learners were recorded to use cognitive and affective strategies more than the male learners. For memory, compensation, and social strategies, the mean score for the male learners is higher, which indicates that male learners use these strategies frequently compared to female learners. For metacognitive strategies, both learners reported equal frequency with a mean score of 1.70 .

From the findings, the young Malaysian ESL learners employed direct and indirect strategies in language learning, hence, this is a great indicator that young 
learners can be trained to use multiple strategies in language acquisition as well as effective language learners. Since language strategy use is closely connected to students' performance (Chang \& Liu, 2013; Ghavamnia et al., 2011), teachers should ensure all young learners in primary school, male or female, apprehend the paramountcy of using LLS in their learning.

Compensation strategies are shown to be used most frequently among young Malaysian ESL learners, reiterating Zhou (2010) observation that learners tend to use these strategies as it is related to the proficiency level of the English learners, particularly in the number of vocabularies retained by the learners. Swathi (1990) stated that compensation strategies are under the direct strategies group that leads to more precise language information such as linguistic training and the modification of learning materials being created. Several basic characteristics of compensation strategies are mother-tongue use and hesitation requests support from others, so that the missed speech in the target language can be given or provided by a teacher or peer. Apart from that, some other unique features in compensation strategies are it allowing the use of gestures or moderately preventing communication when facing complexity in communication. Hence, as the young learners are still lacking in vocabulary and language knowledge, they tend to use compensation strategies to achieve the goals in communication.

Female learners were more frequent users of cognitive strategies compared to male learners which is consistent with past studies (Teh et al., 2009; Kaur \& Embi, 2011; Razak et al., 2012). Zhou (2010) said that in general, females are better than males in English language learning. This can be linked to consumers of English learning strategies since female learners used more learning strategies to learn effectively. Furthermore, Zhou (2010) also says that female learners strive to use learning strategies to better their education, while male learners are tolerant of letting loose and play. Evidence from this research further confirms the conclusion of L2 acquisition studies that not only females are better than males in L1 and L2, but also in a foreign language (Slik et al., 2015).

Teachers play a key role in stimulating the application of learning strategies among the learners. The numerous profits offered by learning strategies contribute towards effective language learning (O'Malley \& Chamot, 1990). They stated that a learning strategy is a thought or behaviour that learners use to help them understand, discover, or preserve additional information. Kaur and Embi (2011) posit that in their language learning, students are entirely dependent on their teacher. Chen (2014) in his study mentioned that language strategies make it possible for learners to become independent learners with a condition that teachers mediate the learners in the target language until learners can manage their learning undertaking. Chen's suggestion might be applicable to all young learners. However, teachers can adapt and adjust to the capacity of young ESL learners. Hence, teachers should have sufficient understanding of learning strategies and thus able to use the approaches and methods that best fit their learners. 


\section{Conclusion}

From the study, it is obvious that identifying LLS plays a significant role in language acquisition. The finding demonstrates the fact that young learners are keen to use different strategies in combination. This significant finding is a stage of advancement for the language teachers or facilitators to assimilate the justifications that lie behind the learner's differences in the language learning context. As young learners have a limited amount of English and are still undergoing their formal education, teachers should identify the factors that influence the strategy used by their students. The knowledge of LLS can significantly contribute to the enhancement of the teaching and learning process. This study itself showed that female learners can vary in their strategic choices and usages from the male learners. To become a successful learner, it is important to distinguish these influences as it provides a practical direction.

To make learning acquisition a success, raising awareness to the learners on the importance of LLS is essential due to the numerous benefits to language learners. Raising student awareness on the plethora of learning strategies and their advantages can help language learners to be more positive towards language acquisition and become efficient learners. This is because the greater collection of language strategies and their frequent use lead to effective learning. Therefore, though the students are young learners, teachers should also enlarge their variety of language strategies in addition to using this opportunity to utilise and gain benefit from existing strategies. Hence, they need to develop a rich atmosphere that applies to learning strategies actively not only inside the classroom but also outside the classroom. It thus induces an active presence in the teaching and learning process by implementing various learning strategies.

One underlying implicit input of this study is that young learners have already used language learning strategies without being aware of them. Therefore, this study makes a major contribution especially to teachers as they can help learners use a wider range of strategies besides discovering new ones. Furthermore, it sheds light on the relevance of language learning experience by assisting individuals to build and sustain positive thinking about learning strategies, which is important for long-term L2 acquisition.

Due to the limited scale of this study-small sample size and homogeneity of participants-future research involving more and wider range of primary school learners should be conducted to further testify the LLS recognised in the present study. Upcoming studies on LLS could explore the new perspective in teaching approach, different variables that exist and how these factors might boost or facilitate certain strategies, which may lead to further insights. Once these strategies can be validated, more effective program strategies can be developed to benefit more ESL learners in Malaysia.

\section{Conflicts of Interest}

The authors declare no conflicts of interest regarding the publication of this paper. 


\section{References}

Al Raqqad, Y. M., Ismail, H. H., \& Al Raqqad, K. M. (2019). The Impact of Reading Strategies on EFL Students: A Research Review. International Journal of English, Literature and Social Science, 4, 2042-2048. https://doi.org/10.22161/ijels.46.65

Anderson, N. J. (2002). The Role of Metacognition in Second Language Teaching and Learning (Vol. 4646). ERIC Clearinghouse on Languages and Linguistics. https://www.govinfo.gov/content/pkg/ERIC-ED463659/pdf/ERIC-ED463659.pdf

Asgari, A., \& Mustapha, G. B. (2011). The Type of Vocabulary Learning Strategies Used by ESL Students in University Putra Malaysia. English Language Teaching, 4, 84-90. https://doi.org/10.5539/elt.v4n2p84

Aziz, A. (2018, December 21). Embrace 21st-Century Learning Approach. The Malaysian Reserve.

https://themalaysianreserve.com/2018/12/21/embrace-21st-century-learning-approach/

Chamot, A. U. (2004). Issues in Language Learning Strategy Research and Teaching. Electric Journal of Foreign Language Teaching, 1, 14-26 https://e-flt.nus.edu.sg/wp-content/uploads/2020/09/v1n12004/chamot.pdf

Chand, Z. A. (2014). Language Learning Strategy Use and Its Impact on Proficiency in Academic Writing of Tertiary Students. Procedia-Social and Behavioral Sciences, 118, 511-521. https://doi.org/10.1016/j.sbspro.2014.02.070

Chang, C. H., \& Liu, H. J. (2013). Language Learning Strategy Use and Language Learning Motivation of Taiwanese EFL University Students. Electronic Journal of Foreign Language Teaching, 10, 196-209. https://e-flt.nus.edu.sg/wp-content/uploads/2020/09/v10n22013/chang.pdf

Chen, M. L. (2014). Age Differences in the Use of Language Learning Strategies. English Language Teaching, 7, 144-151. https://doi.org/10.5539/elt.v7n2p144

Chong, M. L., Tan, B. H., \& Abdullah, M. H. (2011). Wiki for Co-Writing a Science Dictionary. Gema OnlineTM Journal of Language Studies, 11, 109-128. https://ejournal.ukm.my/gema/article/view/45/39

Cohen, A. D. (1998). Strategies in Learning and Using a Second Language. Teaching English as a Second or Foreign Language-The Electronic Journal for English as a Second Language, 3. http://www.tesl-ej.org/wordpress/issues/volume3/ej12/ej12r10/

David, A. R., Thang, S. M., \& Azman, H. (2015). Accommodation Low Proficiency ESL Students' Language Learning Needs Through an Online Writing Support System. e-Bangi, Journal of Social Sciences and Humanities, 12, 118-127. https://ejournal.ukm.my/ebangi/article/view/11001

Felix, S. (1981). On the (in) Applicability of Piagetian thought to Language Learning. Studies in Second Language Acquisition, 3, 179-192.

http://www.jstor.org/stable/44487211 https://doi.org/10.1017/S0272263100004162

Garba, S. A., Byabazaire, Y., \& Busthami, A. H. (2015). Towards the Use of 21st Century Teaching-Learning Approaches: The Trend of Development in Malaysian Schools within the Context of Asia Pacific. International Journal of Emerging Technologies in Learning, 10, 72-79. https://doi.org/10.3991/ijet.v10i4.4717

Gerami, M. H., \& Baighlou, S. M. G. (2011). Language Learning Strategies Used by Successful and Unsuccessful Iranian EFL Students. Procedia-Social and Behavioural Sciences, 29, 1567-1576. https://doi.org/10.1016/j.sbspro.2011.11.399

Ghavamnia, M., Kassaian, Z., \& Dabaghi, A. (2011). The Relationship between Language Learning Strategies, Language Learning Beliefs, Motivation, and Proficiency: A Study 
of EFL Learners in Iran. Journal of Language Teaching \& Research, 2, 1156-1161. https://doi.org/10.4304/jltr.2.5.1156-1161

Habok, A., \& Magyar, A. (2018). The Effect of Language Learning Strategies on Proficiency, Attitudes and School Achievement. Frontiers in Psychology, 8, Article No. 2358. https://doi.org/10.3389/fpsyg.2017.02358

Iamudom, T., \& Tangkiengsirin, S. (2020). A Comparison Study of Learner Autonomy and Language Learning Strategies among Thai EFL Learners. International Journal of Instruction, 13, 199-212. https://files.eric.ed.gov/fulltext/EJ1249113.pdf https://doi.org/10.29333/iji.2020.13214a

Kaur, M., \& Embi, M. A. (2011). The Relationship between Language Learning Strategies and Gender among Primary School Students. Theory and Practice in Language Studies, 1, 1432-1436. https://doi.org/10.4304/tpls.1.10.1432-1436

Lee, C. K. (2010). An overview of Language Learning Strategies. Annual Review of Education, Communication, and Language Sciences, 7, 132-152. https://core.ac.uk/download/pdf/25889647.pdf

Lessard-Clouston, M. (1997). Language Learning Strategies: An Overview for L2 Teachers. The Internet TESL Journal, 3, 1-16. https://www.researchgate.net/publication/269997462_Language_Learning_Strategies_ An_Overview_for_L2_Teachers

Li, J. (2020). An Empirical Study on Learning Strategies of Chinese ESL Learners. Foreign Language Education, 23, 42-49. http://en.cnki.com.cn/Article_en/CJFDTOTAL-TEAC200201008.htm

Martínez, I. (1996). The Importance of Language Learning Strategies in Foreign Language Teaching. English Philology Notebooks, 5, 103-120.

https://www.researchgate.net/publication/28203603_The_importance_of_language_lea rning_strategies_in_foreign_language_teaching

Muhamad, M., \& Seng, G. H. (2019). Teachers' Perspective of 21st Century Learning Skills in Malaysian ESL Classrooms. International Journal of Advanced and Applied Sciences, 6, 32-37. https://doi.org/10.21833/ijaas.2019.10.006

Nemati, A. (2009). Memory Vocabulary Learning Strategies and Long-Term Retention. International Journal of Vocational and Technical Education, 1, 14-24. https://academicjournals.org/article/article1379328836_Nemati.pdf https://doi.org/10.4314/marang.v20i1.56821

O’Malley, J. M., \& Chamot, A. U. (1990). Learning Strategies in Second Language Acquisition. Cambridge University Press. https://doi.org/10.1017/CBO9781139524490

Osman, K., Soh, T. M. T., \& Arsad, N. M. (2010). Development and Validation of the Malaysian 21st Century Skills Instrument (M-21CSI) for Science Students. Procedia-Social and Behavioral Sciences, 9, 99-603. https://doi.org/10.1016/j.sbspro.2010.12.204

Padmaja, C. V., \& Reddy, P. S. (2019). Cognizance of Language Learning Strategies-The Need of the Hour. International Journal of Recent Technology and Engineering, 8, 1620-1621. https://doi.org/10.35940/ijrte.C4224.098319 https://www.ijrte.org/wp-content/uploads/papers/v8i3/C4224098319.pdf

Piaget, J. (1964). Part I: Cognitive Development in Children: Piaget, Development and Learning. Journal of Research in Science Teaching, 2, 176-186. https://doi.org/10.1002/tea.3660020306

Rahimi, A., \& Bigdeli, R. A. (2014). A Therapeutic Turn in Language Teaching. Language and Culture Education: Current Perspectives and Future Directions. The 4th Annual ILAC International Conference on "Language and Culture Education: Current Pers- 
pectives and Future Directions", Bangkok, 22-23 July 2014, 1-11.

https://www.researchgate.net/publication/273635497_A_Therapeutic_Turn_in_Langua ge_Teaching

Ramiza, D., \& Albion, P. (2013). English Language in Malaysian Education System: Its Existence and Implication. 3rd Malaysian Postgraduate Conference, Sydney, 3-4 July 2013, 1-10.

https://www.researchgate.net/publication/279867616_ENGLISH_LANGUAGE_IN_M ALAYSIAN_EDUCATION_SYSTEM_ITS_EXISTENCE_AND_IMPLICATION

Razak, N. Z. A., Ismail, F., Aziz, A. A., \& Babikkoi, M. A. (2012). Assessing the Use of English Language Learning Strategies among Secondary School Students in Malaysia. Procedia-Social and Behavioral Sciences, 66, 240-246. https://doi.org/10.1016/j.sbspro.2012.11.266

Rehman, A. U., Khan, K., Almas, A., Mohamad, M., \& Ismail, N. H. (2020). Teachers' Teaching Reading Strategies at Public Elementary Schools in Haripur District. Creative Education, 11, 468-478. https://doi.org/10.4236/ce.2020.114034

Rusli, R., Yunus, M., \& Hashim, H. (2018). Low Speaking Proficiency among the Malaysian Undergraduates: Why and How? e-Proceedings of the International Conference on Social Sciences and Humanities, 23-24 April 2018, 678-689. http://conference.kuis.edu.my/pasak3/images/eprosiding1/PASAK3_2220.pdf

Saad, N. S. M., Sidek, H. H. M., Baharun, H., Idrus, M. M., \& Yunus, M. M. (2016). A Conceptual Framework to Explore the English Language Learning Experiences of International Students in Malaysia. International E-Journal of Advances in Education, 2, 453-464. https://doi.org/10.18768/ijaedu.281043

Sepasdar, M., \& Soori, A. (2014). The Impact of Age on Using Language Learning Strategies. International Journal of Education and Literacy Studies, 2, 26-31. https://doi.org/10.7575/aiac.ijels.v.2n.3p.26

Simsek, A., \& Balaban, J. (2010). Learning Strategies of Successful and Unsuccessful University Students. Contemporary Educational Technology, 1, 36-45. https://doi.org/10.30935/cedtech/5960 https://files.eric.ed.gov/fulltext/ED542214.pdf

Slik, F., Hout, R., \& Schepens, J. (2015). The Gender Gap in Second Language Acquisition: Gender Differences in the Acquisition of Dutch among Immigrants from 88 Countries with 49 Mother Tongues. PLoS ONE, 10, e0142056. https://doi.org/10.1371/journal.pone.0142056

Steels, L. (2003). Social Language Learning. In The Future of Learning (pp. 133-162). IOS Press.

$\underline{\text { https://citeseerx.ist.psu.edu/viewdoc/download?doi=10.1.1.77.1753\&rep=rep1\&type }=\text { p }}$ df

Subramaniam, B., \& Palanisamy, K. (2014). The Usage of Language Learning Strategies in Malaysian Private Secondary Schools. Advances in Language and Literary Studies, 5, 96-101. https://doi.org/10.7575/aiac.alls.v.5n.4p.96

Swathi, V. (1990). Language Learning Strategies: What Every Teacher Should Know by Rebecca L. Oxford. Issues in Applied Linguistics, 1, 116-120. https://escholarship.org/content/qt1446j36q/qt1446j36q.pdf

Syafryadin, S. (2020). Students' Strategies in Learning Speaking: Experience of Two Indonesian Schools. Journal for Language and Foreign Language Learning, 9, 34-47. https://doi.org/10.21580/vjv9i14791

Tahang, H., Sarmin, S., Yuliana, A. \& Taslim, T. (2018). Language Learning Strategies Employed by Successful Students in Developing English-Speaking Performance. 
E-Journal Qalam: Jurnal Ilmu Kependidikan, 7, 56-65. https://doi.org/10.33506/jq.v7i1.354

Teh, K. S. M., Embi, M. A., Nik Yusoff, N. M. R., \& Mohamod, Z. (2009). A Closer Look at Gender and Arabic Language Learning Strategies Use. European Journal of Social Sciences, 9, 399-407.

https://www.researchgate.net/publication/268419377_A_Closer_Look_at_Gender_and _Arabic_Language_Learning_Strategies_Use

Ting, S. H., Marzuki, E., Chuah, K. M., Misieng, J., \& Jerome, C. (2017). Employers' view on the Importance of English Proficiency and Communication Skills for Employability in Malaysia. Indonesian Journal of Applied Linguistics, 7, 215-327.

Tran, T. V. (1988). Sex Differences in English Language Acculturation and Learning Strategies among Vietnamese Adults Aged 40 and over in the United States. Sex Roles, 19, 747-758. https://doi.org/10.1007/BF00288990

Vance, S. J. (1999). Language Learning Strategies: Is There a Best Way to Teach Them? https://files.eric.ed.gov/fulltext/ED438716.pdf

Viriya, C., \& Sapsirin, S. (2014). Gender Differences in Language Learning Styles and Language Learning Strategies. Indonesian Journal of Applied Linguistics, 3, 77-88.

Wael, A., Asnur, M. N. A., \& Ibrahim, I. (2018). Exploring Students' Learning Strategies in Speaking Performance. International Journal of Language Education, 2, 65-71. https://doi.org/10.26858/ijole.v2i1.5238

Wafa, S. (2003). Language Learning Strategy Use in Palestine. Teaching English as a Second Language. Electric Journal TESL-EJ, 7.

http://www.tesl-ej.org/wordpress/issues/volume7/ej26/ej26a3/

Webb, S. (2007) The Effects of Synonymy on Second-Language Vocabulary Learning. Reading in a Foreign Language, 19, 120-136.

Weng, P. L. P., Yunus, M. M., \& Embi, M. A. B. (2016). Successful Language Learning Strategies Used by Successful Year 5 English as a Second Language (ESL) Learners. Proceedings of the ICECRS, 1, 539-548. http://doi.org/10.21070/picecrs.v1i1.523

Wharton, G. (2000). Language Learning Strategy Use of Bilingual Foreign Language Learners in Singapore. Language Learning, 50, 203-243.

https://doi.org/10.1111/0023-8333.00117

Wong, L. L. C., \& Nunan, D. (2011). The Learning Styles and Strategies of Effective Language Learners. System, 39, 144-163. https://doi.org/10.1016/j.system.2011.05.004

World Economic Forum (2016, March). New Vision for Education: Fostering Social and Emotional Learning through Technology. World Economic Forum. http://www3.weforum.org/docs/WEF_New_Vision_for_Education.pdf

Yunus, M. M., Sulaiman, N. A., \& Embi, A. E. (2013). Malaysian Gifted Students' Use of English Language Learning Strategies. English Language Teaching, 6, 97-109. https://doi.org/10.5539/elt.v6n4p97

Zare, P. (2012). Language Learning Strategies among EFL/ESL Learners: A Review of Literature. International Journal of Humanities and Social Science, 2, 162-169. http://www.ijhssnet.com/journals/Vol_2_No_5_March_2012/20.pdf

Zhou, Y. (2010). English Language Learning Strategy Use by Chinese Senior High School Students. English Language Teaching, 3, 152-158. https://doi.org/10.5539/elt.v3n4p152 